\title{
Diet composition and feeding habits of the eyespot skate, Atlantoraja cyclophora (Elasmobranchii: Arhynchobatidae), off Uruguay and northern Argentina
}

\author{
Santiago A. Barbini ${ }^{1}$ and Luis O. Lucifora ${ }^{2}$
}

The eyespot skate, Atlantoraja cyclophora, is an endemic species from the southwestern Atlantic, occurring from Rio de Janeiro, Brazil, to northern Patagonia, Argentina. The feeding habits of this species, from off Uruguay and north Argentina, were evaluated using a multiple hypothesis modelling approach. In general, the diet was composed mainly of decapod crustaceans, followed by teleost fishes. Molluscs, mysidaceans, amphipods, isopods, lancelets and elasmobranchs were consumed in lower proportion. The consumption of shrimps drecreased with increasing body size of $A$. cyclophora. On the other hand, the consumption of teleosts increased with body size. Mature individuals preyed more heavily on crabs than immature individuals. Teleosts were consumed more in the south region $\left(34^{\circ}-38^{\circ} \mathrm{S}\right)$ and crabs in the north region $\left(38^{\circ}-\right.$ $41^{\circ} \mathrm{S}$ ). Shrimps were eaten more in the warm season than in the cold season. Prey size increased with increasing body size of A. cyclophora, but large individuals also consumed small teleosts and crabs. Atlantoraja cyclophora has demersal-benthic feeding habits, shifts its diet with increasing body size and in response to seasonal and regional changes in prey availability and distribution.

La raya de círculos, Atlantoraja cyclophora, es una especie endémica del Atlántico Sudoccidental, que se distribuye desde Río de Janeiro, Brasil, hasta el norte de la Patagonia, Argentina. Los hábitos alimentarios de esta especie fueron evaluados frente a la costa de Uruguay y norte de Argentina, utilizando un enfoque de modelado de múltiples hipótesis. En general, la dieta estuvo compuesta principalmente por crustáceos decápodos (71,37 \%IRI), seguido de peces teleósteos $(28,54$ \%IRI). En menor proporción fueron consumidos moluscos, misidáceos, anfípodos, isópodos, anfioxos y elasmobranquios. El consumo de decápodos Natantia disminuyó con el incremento del tamaño del cuerpo de $A$. cyclophora. Por otro lado, el consumo de teleósteos se incrementó con el incremento del tamaño del cuerpo. Individuos maduros consumieron cangrejos en mayor proporción que individuos inmaduros. Los teleósteos fueron consumidos mayormente en la región sur $\left(34^{\circ}-38^{\circ} \mathrm{S}\right)$ y los cangrejos en la región norte $\left(38^{\circ}-41^{\circ} S\right)$. Los decápodos Natantia fueron más consumidos en la estación cálida que en la estación fría. El tamaño de las presas consumidas se incrementó con el aumento del tamaño corporal de A. cyclophora, pero individuos de mayor tamaño no abandonadon el consumo de pequeños cangrejos y teleósteos. Atlantoraja cyclophora presenta hábitos alimentarios demersal-bentónicos, cambia su dieta con el incremento del tamaño corporal y en respuesta a cambios estacionales y regionales en la disponibilidad y distribución de las presas.

Keywords: Chondrichthyes, Ontogenetic shifts, Predation, Southwest Atlantic.

\section{Introduction}

The eyespot skate, Atlantoraja cyclophora (Regan, 1903), is a member of the family Arhynchobatidae and it is an endemic species from the southwestern Atlantic, occurring from Rio de Janeiro, Brazil $\left(22^{\circ} \mathrm{S}\right)$ to northern Patagonia, Argentina ( $42^{\circ}$ S) (Menni \& Stehmann, 2000; Bovcon et al., 2011). Typically, this species inhabits depths ranging from the shoreline to $150 \mathrm{~m}$ and it reaches a maximun total length of $695 \mathrm{~mm}$ (Cousseau et al., 2007). Off Uruguay and southern Brazil waters, A. cyclophora matures at 463-485 $\mathrm{mm}$ and 528-532 $\mathrm{mm}$ total length for male and female, respectively (Oddone \& Vooren 2005; Oddone et al., 2008). Like other skate species along the coastal and continental shelf waters from north Argentina and Uruguay, A. cyclophora is subjected to heavy fishing

\footnotetext{
${ }^{1}$ Laboratorio de Ictiología, Instituto de Investigaciones Marinas y Costeras, Universidad Nacional de Mar del Plata, Consejo Nacional de Investigaciones Científicas y Técnicas (CONICET), Funes 3350, Mar del Plata, B7602AYL, Buenos Aires, Argentina. sbarbini@mdp.edu.ar (corresponding author)

${ }^{2}$ Instituto de Biología Subtropical - Iguazú, Universidad Nacional de Misiones, Consejo Nacional de Investigaciones Científicas y Técnicas (CONICET), Casilla de Correo 9, Puerto Iguazú, N3370AVQ, Misiones, Argentina. luis.lucifora@conicet.gov.ar
} 
pressure in multi-species fisheries for coastal demersal species (Tamini et al., 2006), with a decreasing trend in population abundance (Massa et al., 2006). Like most elasmobranchs, A. cycplohora may be particularly sensitive to fishing pressure, therefore this species is categorized as vulnerable by the International Union for the Conservation of Nature (IUCN) (Massa et al., 2006).

Indirect effects of a heavy fishing pressure include disruption of trophic interactions through selective removal of predator or prey species, removal of competitors and species replacement (Stevens et al., 2000; Bornatowaki et al., 2014; Navia et al., 2016). Thus, knowledge of potential ecological consequences of declines in the abundance of predators is critical for fisheries and marine ecosystem management (Heithaus et al., 2008). For this reason, information on feeding habits and trophic interactions between species are very important and necessary ecological parameters for the correct management and protection of fisheries (Navia et al., 2016). Despite that, catches of skates off Argentina increased markedly in recent years (Hozbor \& Massa, 2012), fishery statistics and ecological traits of these species are scarcely known, specially for $A$. cyclophora.

From a trophic viewpoint, skates may have an important role in structuring marine communities due to their wide distribution and high abundance (Ebert \& Bizzarro, 2007). These roles in the marine communities can be influenced by traits of the predator (e.g. sex, maturity stage and body size) and extrinsic factors (e.g. season and region) (Di Giácomo \& Perier, 1996; Lucifora, 2003). Therefore, there is a need to investigate the diet of skates with emphasis on ontogenetic, seasonal and regional variation. This information about life history and trophic interactions must be known and incorporated into future analyses, to accurately evaluate the population dynamics (Schmitt et al., 2015). Information on the feeding habits of $A$. cyclophora is scarce. Diet composition has been studied in detail only off the southern coast of Rio de Janeiro, Brazil, near Ilha Grande, where A. cyclophora preys mainly on crustaceans and teleosts, with seasonal differences in diet composition (Viana \& Vianna, 2014).

In coastal waters off Uruguay and northern Argentina, the skate species Atlantoraja castelnaui (Miranda Ribeiro, 1907), Rioraja agassizii (Müller \& Henle, 1841) and Sympterygia acuta Garman, 1877, that co-occur in space and time with A. cyclophora, showed a consistent regional shift in the diet composition: teleosts were consumed more in the southern part of this region, whereas decapods were eaten more in the northern part (Barbini \& Lucifora, 2011; $2012 ; 2016)$. Therefore, we expected to find the same spatial pattern in A. cyclophora.

We examined the food habits of A. cyclophora off Uruguay and north Argentina. The specific aims of the study were to: (1) describe diet composition; (2) identify changes in diet with sex, maturity stage, body size, season and region; and (3) examine relationships between predator size and prey size.

\section{Material and Methods}

Study area and sampling. The study area is located off Uruguay and northern Argentina, between $34^{\circ} \mathrm{S}$ and $41^{\circ} \mathrm{S}$ (Fig. 1). The northern area is characterized by a stratified coastal zone influenced by the discharge of the Río de la Plata. On the other hand, the southern area is a homogeneous coastal zone, that comprises an estuarine system, called El Rincón, characterized by the discharge of the Negro and Colorado Rivers and discharges of high salinity waters of the San Matías Gulf (Guerrero \& Piola, 1997; Lucas et al., 2005).

Samples of $A$. cyclophora were taken from scientific trawl surveys conducted by the Instituto Nacional de Investigación y Desarrollo Pesquero (INIDEP, Argentina) and from commercial landings of the coastal fleet of Mar del Plata harbour (Fig. 1) during December 2005, February, May, June, September and November 2006, April, May, July, August, October, November and December 2007. Total length (TL, mm), sex and maturity stage (juvenile or adult) of each individual were recorded. The maturity stage was determined according to the presence of eggs and observation of the uteri, oviducal glands and ovarian follicles in females and to the degree of calcification of the claspers and the development of testes and reproductive ducts in males (Colonello et al., 2011). The stomachs were removed and stored at $-20^{\circ} \mathrm{C}$. In the laboratory, prey were sorted, identified to the lowest possible taxonomic level using published catalogues, counted and wet weight was recorded $( \pm 0.01 \mathrm{~g})$. Whenever possible, carapace width (CW) of crabs, cephalothorax length (CL) of shrimps and total lenght (TL) of teleosts were measured.

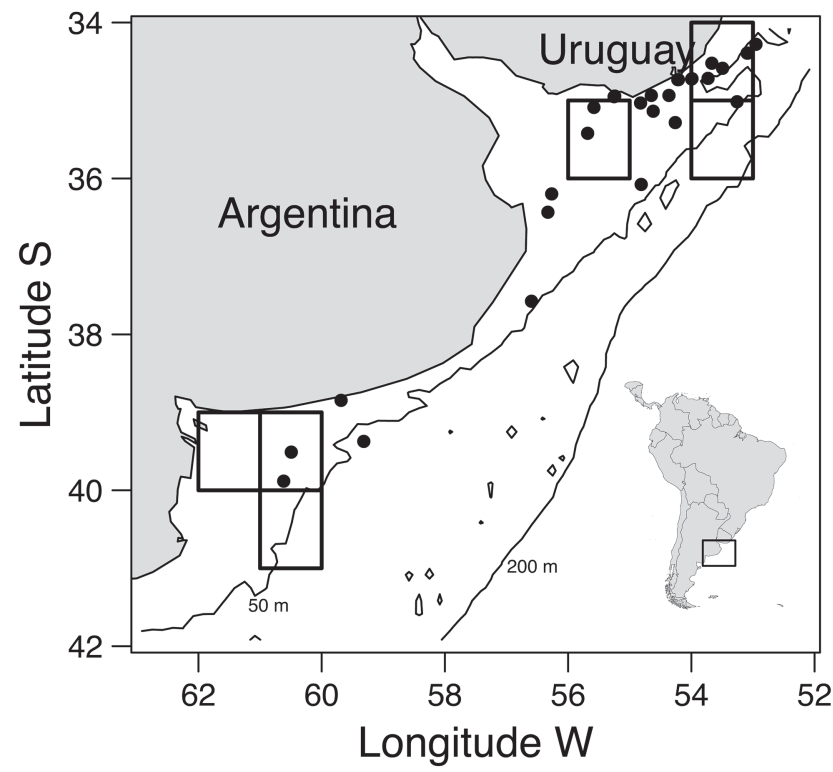

Fig. 1. Study area showing the location of trawl stations (black dots) and cells of the fishing grid (black rectangles) where individuals of Atlantoraja cyclophora were captured off North Argentina and Uruguay. 
Diet and data analysis. Percentage by frequency of occurrence $(\% \mathrm{O})$, number $(\% \mathrm{~N})$, weight $(\% \mathrm{~W})$ and index of relative importance (\%IRI; Pinkas et al., 1971; Cortés, 1997) for each prey were used to describe the diet of $A$. cyclophora. To determine whether a sufficient number of individuals was sampled to conduct statistical analyses, the order of stomachs was randomised 100 times and the mean cumulative Shannon diversity index was plotted as a function of sample size. Sample size was considered sufficient to describe diet if the cumulative prey curve reached an asymptote (Magurran, 2004).

Prey were grouped into four categories for the statistical analyses: shrimps, crabs, teleosts and cephalopods. mysidaceans, amphipods, isopods, lancelets, gastropods, polychaetes and elasmobranchs were excluded from the comparative analysis because they had $\% \mathrm{~N}<1$. For each prey category, we fitted generalized linear models (GLM) (Venables \& Ripley, 2002), where response variable was the number of prey consumed by A. cyplophora, and independent variables were sex, body size (TL), matury stage (immature and mature), season (warm = October-March; cold $=$ April-September) and region (north $=34^{\circ}-38^{\circ} \mathrm{S}$; south $=38^{\circ}-41^{\circ} \mathrm{S}$ ). Also, models with combinations among independent variables were fitted. A model without any of the independent variables (i.e. null model) was fitted to assess if none of the tested variables had an effect on the consumption of prey categories. All models had a negative binomial error distribution and a log link (Venables \& Ripley, 2002).

The significance of each model was tested using a multiple-hypothesis modelling approach (Anderson et al., 2000; Franklin et al., 2001), therefore each model was considered as a hypothesis explaining the consumption of a particular prey category. For each model fitted, the Akaike information criterion (AIC) and the Akaike's weight $(w)$ were calculated. The value of the AIC for a given model represents the information lost, so the model with the lowest AIC was selected as the best model among all within the set of candidate models. $w$ provides a measure of the strength of evidence for each model and represents the probability that the model is the best among the whole set of candidate models (Franklin et al., 2001; Johnson \& Omland, 2004). If $w$ did not provide strong support for any particular model, we used model averaging to stimate the parameters of the variables included in the best model (Symonds \& Moussalli, 2011).

To examine the relationships between predator size and prey size, we used TL of A. cyclophora and CW of crabs, LC of shrimps and TL of teleosts. Regressions on the 5,50 and $95 \%$ quantiles were fitted in order to test an increase in minimum, medium and maximum prey size with increasing TL of A. cyplophora, respectively (Scharf et al., 1998). All statistical analyses were performed using the R statistical software, version 3.1.0. (R Development Core Team, 2012).

\section{Results}

Overall, 442 individuals were sampled and the $75.8 \%$ (335) contained food. Of the individuals with stomachs containing food, 176 were females (245-686 mm TL) and 159 were males (210-670 $\mathrm{mm} \mathrm{TL})$. Cumulative mean Shannon diversity index curves for all the groups considered reached an asymptote, indicating that sample sizes were sufficient for comparisons (Fig. 2).

In terms of \%IRI, the diet from A. cyclophora included mainly decapods, followed of teleost fishes. Molluscs, mysidaceans, amphipods, isopods, lancelets and elasmobranchs were also consumed but in lower proportion (Table 1). Among decapods, Artemesia longinaris, Pleoticus muelleri and Pontocaris boschii were the most consumed prey species in terms of $\% \mathrm{~N}$ and $\%$ O. Dules auriga was the most important prey species among teleosts in terms of $\% \mathrm{~N}, \% \mathrm{~W}$ and $\% \mathrm{O}$.

Several patterns were found between the number of prey consumed and maturity stage, TL, season and region (Table 2; Fig. 3). All prey categories were independent of sex. The consumption of shrimps decreased with TL and it was more important in the warm season than in the cold season. In the warm season, the most important shrimps in the diet were Artemesia longinaris and Pleoticus muelleri (Fig. 4). Mature individuals of A. cyplophora preyed more heavily on crabs than immatute individuals, and this consumption was higher in the north region than in the south region. On the other hand, the consumption of teleosts increased with TL of $A$. cyplophora and they were more consumed in the south region than in the north region. The teleost species more consumed in the south region were Dules auriga, Porichthys porosissimus, Trachurus lathami, Mullus argentinae, Etropus longimanus and Symphurus spp.; unidentified teleosts had also a great contribution (Fig. 4). Cephalopods had no significant relationship with any of the independent variables evaluated. As shrimps and crabs had a low $w$, model averaging was computed. The averaged coefficients for shrimps were -0.0016 (s.e. $=$ $0.0014)$ for TL $(w=0.60)$ and -0.366 (s.e. $=0.237)$ for cold season $(w=0.82)$. For crabs the averaged coefficient were -0.179 (s.e. $=0.276)$ for immature $(w=0.36)$ and -0.611 (s.e. $=0.302)$ for south region $(w=0.90)$.

As TL of $A$. cyclophora increased, minimum, medium and maximum LC of shrimps increased (slopes and intercepts of 5,50 and $95 \%$ quantile regressions $=$ 0.022 and $-3.513 ; 0.032$ and $-3.761 ; 0.019$ and 10.789 , respectively, $\mathrm{p}<0.01$ ). However, only maximun $\mathrm{CW}$ of crabs increased significantly with TL of $A$. cyclophora (slope and intercept of $95 \%$ quantile regressions $=0.405$ and $-113.968, \mathrm{p}<0.05)$. Further, as TL of $A$. cyclophora increased, maximum TL of teleosts increased significantly (slope and intercept of $95 \%$ quantile regressions $=0.303$ and -21.621, p < 0.05) (Fig. 5). 


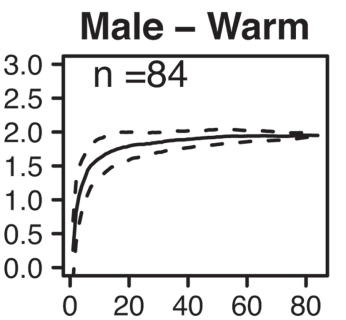

Immature - Warm

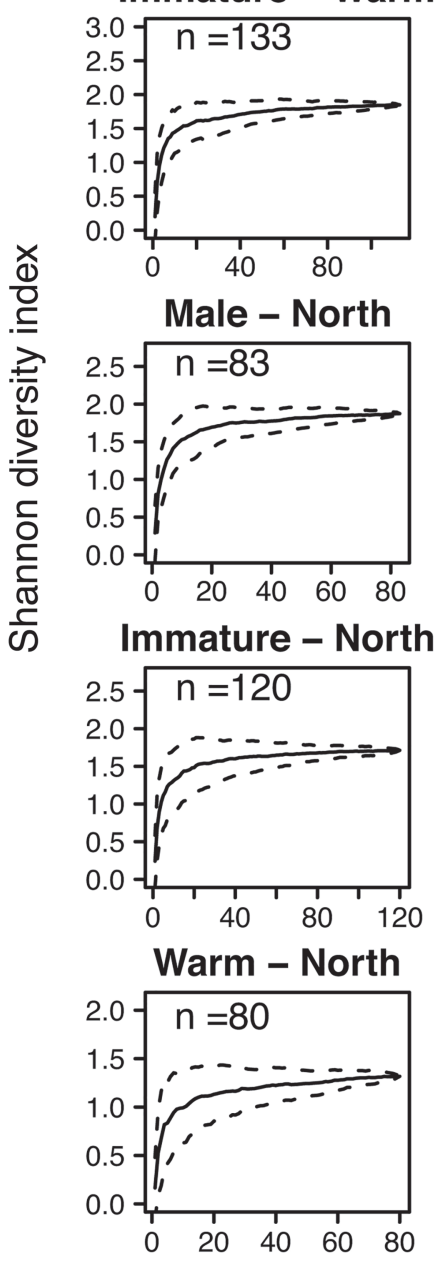

Female - Warm

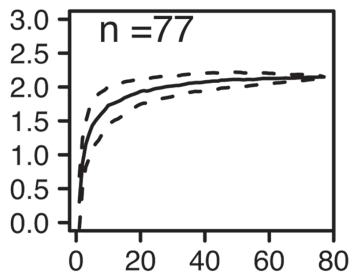

Mature - Warm
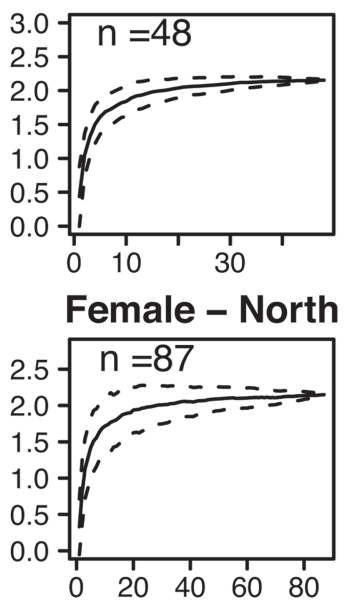

Mature - North

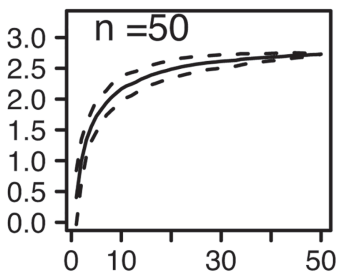

Cold - North

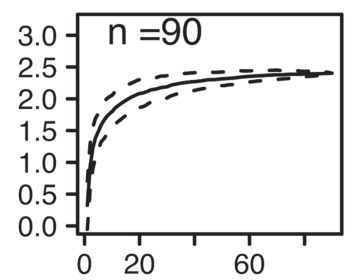

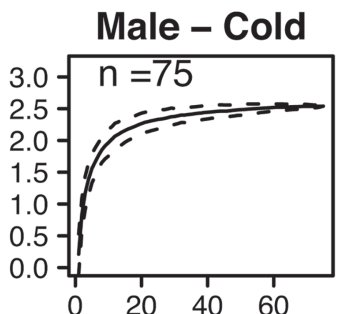

Immature - Cold
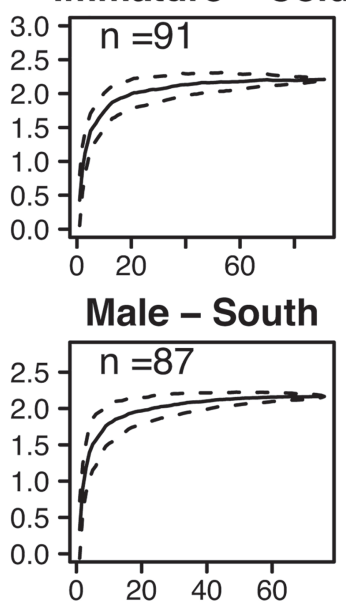

Immature - South

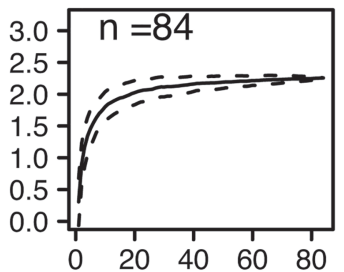

Warm - South

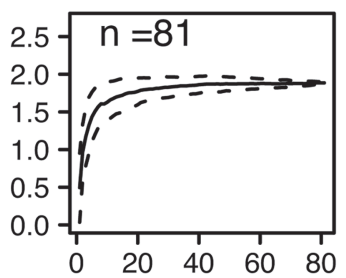

Female - Cold

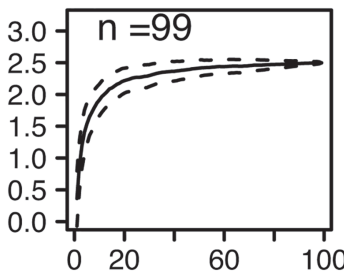

Mature - Cold

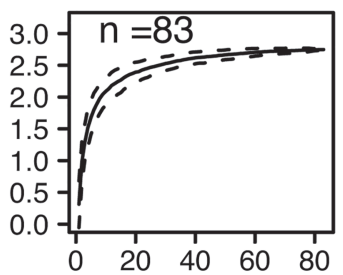

Female - South

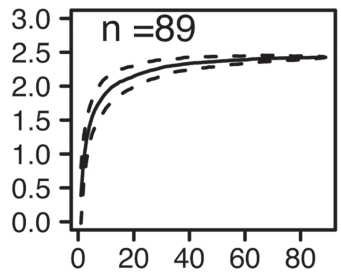

Mature - South

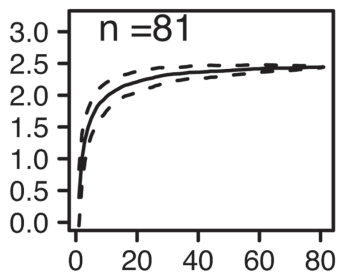

Cold - South

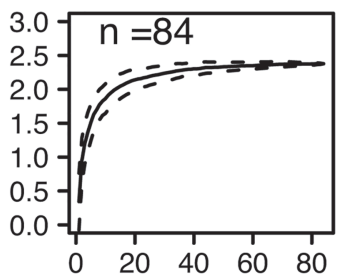

Sample size

Fig. 2. Cumulative mean Shannon diversity index as a function of sample size for prey of Atlantoraja cyclophora from off Uruguay and northern Argentina. Dashed lines indicate standard deviation.

Table 1. Diet composition of Atlantoraja cyclophora off Uruguay and northern Argentina. \%O, percentage frequency of occurrence; $\% \mathrm{~N}$, percentage by number; $\% \mathrm{~W}$, percentage by weight; IRI, index of relative importance; \%IRI, percentage IRI.

\begin{tabular}{|c|c|c|c|c|c|c|}
\hline Prey & & $\% \mathrm{O}$ & $\% \mathrm{~N}$ & $\% \mathrm{~W}$ & IRI & $\%$ IRI \\
\hline TELEOSTEI & & 42.98 & 19.28 & 59.78 & 3398.4 & 28.54 \\
\hline Unidentified teleosts & & 24.18 & 8.34 & 15.29 & 571.38 & \\
\hline \multirow[t]{2}{*}{ Engraulidae } & Anchoa marinii & 0.30 & 0.18 & 0.45 & 0.19 & \\
\hline & Engraulis anchoita & 0.60 & 0.18 & 0.42 & 0.36 & \\
\hline Ophididae & Raneya brasiliensis & 2.98 & 1.11 & 3.12 & 12.64 & \\
\hline Batrachoididae & Porichthys porosissimus & 2.69 & 0.83 & 5.31 & 16.50 & \\
\hline Triglidae & Prionotus nudigula & 1.19 & 0.37 & 0.74 & 1.33 & \\
\hline Serranidae & Dules auriga & 9.55 & 4.17 & 16.21 & 194.71 & \\
\hline
\end{tabular}


Table 1. (conclusion).

\begin{tabular}{|c|c|c|c|c|c|c|}
\hline Prey & & $\% \mathrm{O}$ & $\% \mathrm{~N}$ & $\% \mathrm{~W}$ & IRI & $\%$ IRI \\
\hline Carangidae & Trachurus lathami & 2.69 & 1.02 & 5.51 & 17.54 & \\
\hline Mullidae & Mullus argentinae & 1.19 & 0.37 & 5.58 & 7.10 & \\
\hline Pinguipedidae & Pinguipes brasilianus & 0.30 & 0.09 & 0.79 & 0.26 & \\
\hline Paralychthyidae & Etropus longimanus & 2.69 & 1.30 & 2.52 & 10.27 & \\
\hline Cynoglossidae & Symphurus spp. & 3.28 & 1.30 & 3.83 & 16.85 & \\
\hline \multicolumn{7}{|l|}{ ELASMOBRANCHII } \\
\hline Rajidae & & 0.89 & 0.56 & 0.19 & 0.67 & $<0.01$ \\
\hline \multicolumn{7}{|l|}{ CRUSTACEA } \\
\hline Decapoda & & 73.43 & 77.57 & 38.18 & 8500.1 & 71.37 \\
\hline Lysiosquillidae & Heterosquilla platensis & 0.30 & 0.09 & 0.05 & 0.04 & \\
\hline Unidientified shrimps & & 17.31 & 13.44 & 4.81 & 315.98 & \\
\hline Penaeidae & Artemesia longinaris & 22.10 & 30.12 & 7.23 & 825.14 & \\
\hline Solenoceridae & Pleoticus muelleri & 13.73 & 13.44 & 9.12 & 309.82 & \\
\hline Caridae & & 0.30 & 0.46 & 0.01 & 0.14 & \\
\hline Crangonidae & Pontocaris boschii & 13.13 & 5.84 & 2.86 & 114.28 & \\
\hline Unidentified Brachyura & & 16.42 & 8.34 & 4.26 & 206.82 & \\
\hline \multirow[t]{3}{*}{ Majidae } & Eurypodius latreillei & 0.30 & 0.18 & 0.09 & 0.08 & \\
\hline & Leurocyclus tuberculosus & 5.37 & 2.04 & 4.28 & 33.97 & \\
\hline & Libinia spinosa & 1.79 & 0.74 & 1.73 & 4.43 & \\
\hline Atelecyclidae & Peltarion spinosulum & 3.28 & 1.11 & 2.74 & 12.65 & \\
\hline \multirow[t]{3}{*}{ Portunidae } & Callinectes sapidus & 1.79 & 1.02 & 0.75 & 3.18 & \\
\hline & Ovalipes trimaculatus & 0.30 & 0.09 & 0.12 & 0.06 & \\
\hline & Coenophtalmus tridentatus & 0.30 & 0.18 & 0.05 & 0.07 & \\
\hline Xanthidae & & 0.30 & 0.18 & 0.03 & 0.06 & \\
\hline \multirow[t]{2}{*}{ Pinnotheridae } & Pinnixa patagoniensis & 0.30 & 0.09 & $<0.01$ & 0.03 & \\
\hline & Pinnixa brevipollex & 0.60 & 0.18 & 0.02 & 0.12 & \\
\hline Mysidacea & & 0.60 & 0.28 & $<0.01$ & 0.17 & $<0.01$ \\
\hline Amphipoda & & 0.60 & 0.28 & $<0.01$ & 0.17 & $<0.01$ \\
\hline Isopoda & & 1.50 & 0.46 & 0.05 & 0.76 & $<0.01$ \\
\hline \multirow[t]{3}{*}{ Serolidae } & Serolis spp. & 0.60 & 0.18 & 0.01 & 0.12 & \\
\hline & Serolis marplatensis & 0.30 & 0.09 & 0.01 & 0.03 & \\
\hline & Serolis polaris & 0.60 & 0.18 & 0.02 & 0.12 & \\
\hline \multicolumn{7}{|l|}{ MOLLUSCA } \\
\hline Cephalopoda & & 2.98 & 1.02 & 1.75 & 8.27 & 0.07 \\
\hline Unidentified cephalopods & & 0.60 & 0.18 & 0.07 & 0.15 & \\
\hline Octopodidae & Octopus tehuelchus & 2.69 & 0.83 & 1.68 & 6.75 & \\
\hline Gasteropoda & & 0.30 & 0.09 & $<0.01$ & 0.03 & $<0.01$ \\
\hline POLYCHAETA & & 0.89 & 0.28 & 0.02 & 0.27 & $<0.01$ \\
\hline \multicolumn{7}{|l|}{ CEPHALOCHORDATA } \\
\hline Branchiostomidae & Branchiostoma platae & 0.60 & 0.18 & $<0.01$ & 0.11 & $<0.01$ \\
\hline
\end{tabular}

Table 2. Best models explaining the consumption in number of the main prey category of Atlantoraja cyclophora off Uruguay and northern Argentina. TL: total length; AIC: Akaike Information criterion; w: Akaike weights. The coefficients of the models are relative to mature individuals, north region and warm season. Standard error in parentheses.

\begin{tabular}{lllll}
\hline Prey categories & Intercep & Coefficients & AIC & $w$ \\
\hline Shrimps & $-2.176(0.327)$ & $-0.002(0.0006) \mathrm{TL}-0.375(0.159)$ cold & 1252.6 & 0.42 \\
Crabs & $-0.195(0.209)$ & $-0.499(0.231)$ immature $-0.736(0.233)$ south & 593.6 & 0.35 \\
Teleosts & $-2.947(0.399)$ & $0.003(0.0007) \mathrm{TL}+0.924(0.166)$ south & 649.1 & 0.98 \\
\hline
\end{tabular}



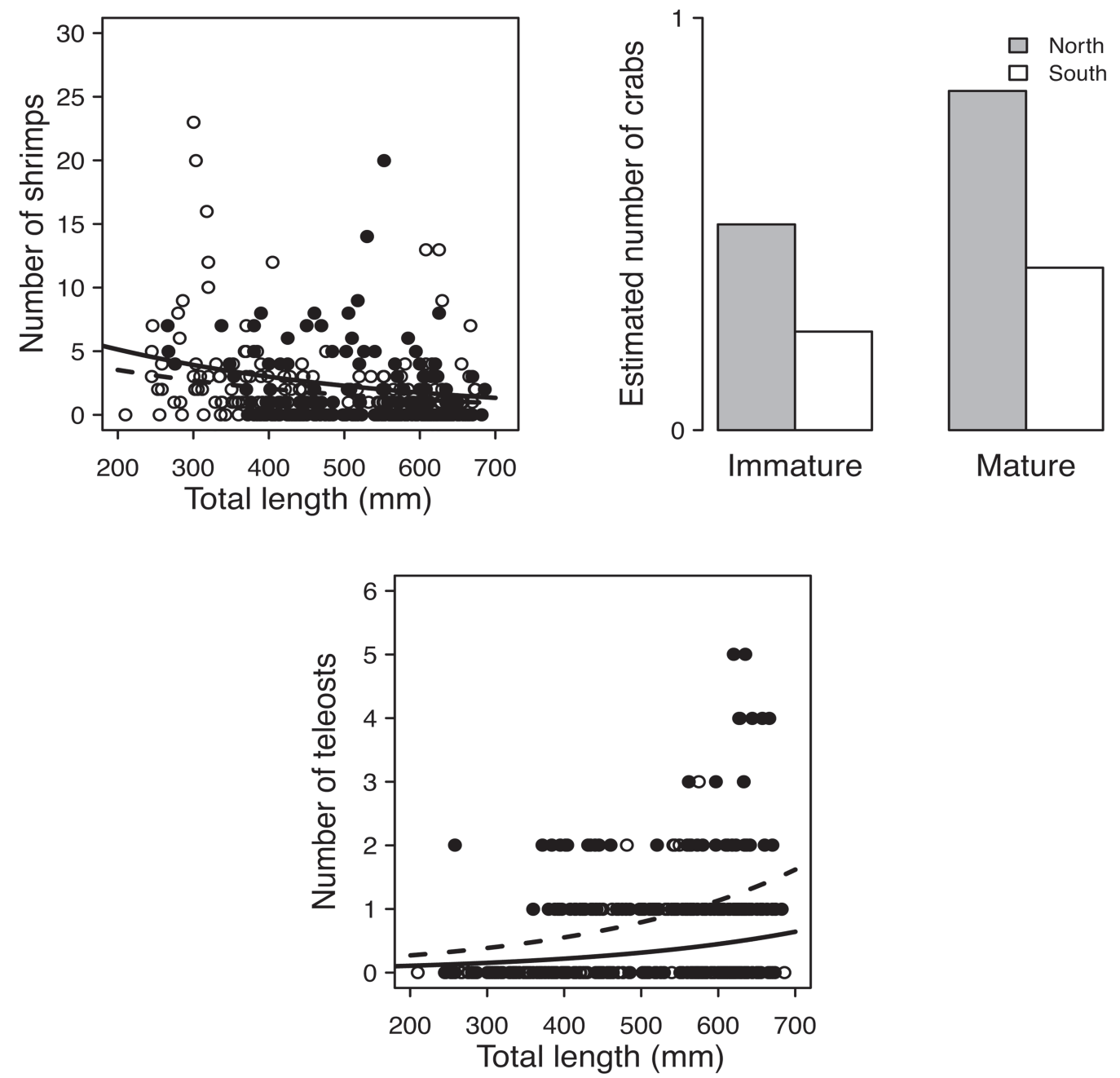

Fig. 3. Changes in consumption of different prey with body size, maturity stage, season and region of Atlantoraja cyclophora from off Uruguay and northern Argentina estimated by generalized linear models for number of shrimps, crabs and teleosts. In shrimps: warm season with solid lines and open circles; cold season with dashed lines and solid circles. In teleosts: north region with solid lines and open circles; south region with dashed lines and solid circles.
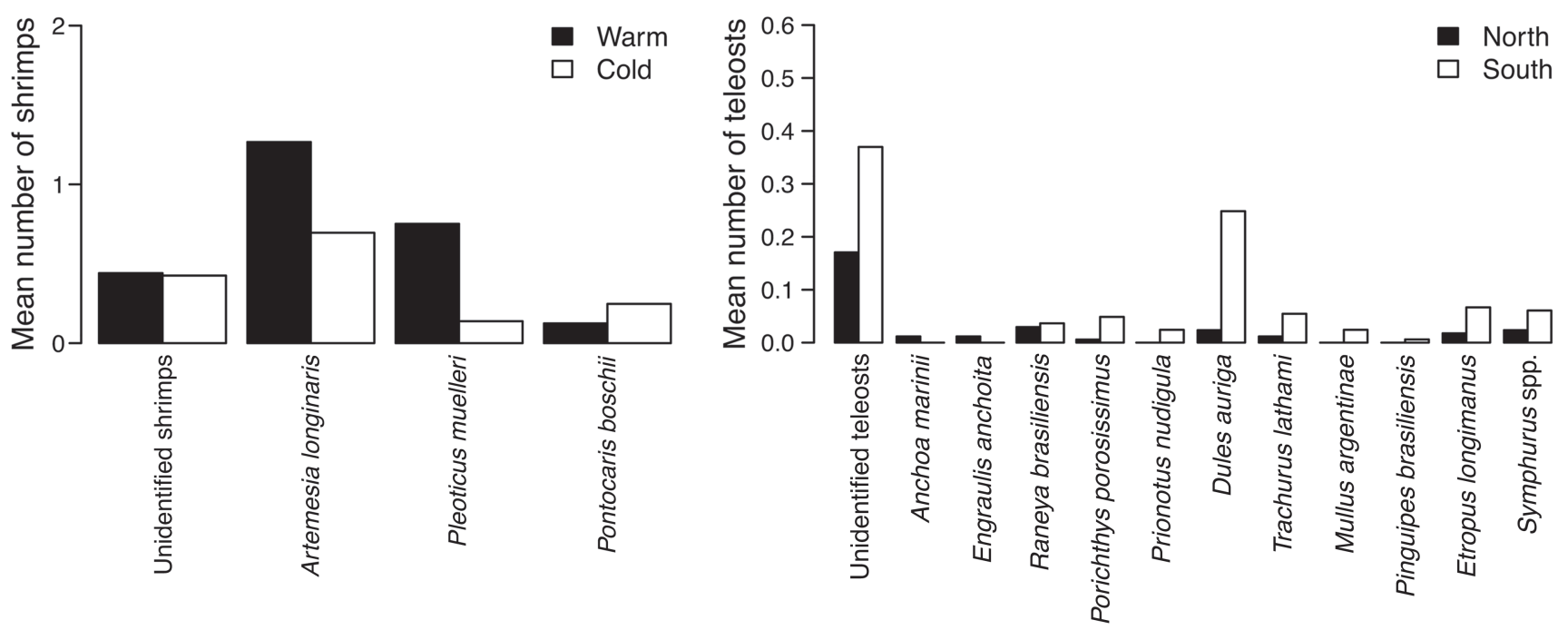

Fig. 4. Mean number of shrimps and teleosts consumed for Atlantoraja cyclophora from off Uruguay and northern Argentina by season and region, respectively. 

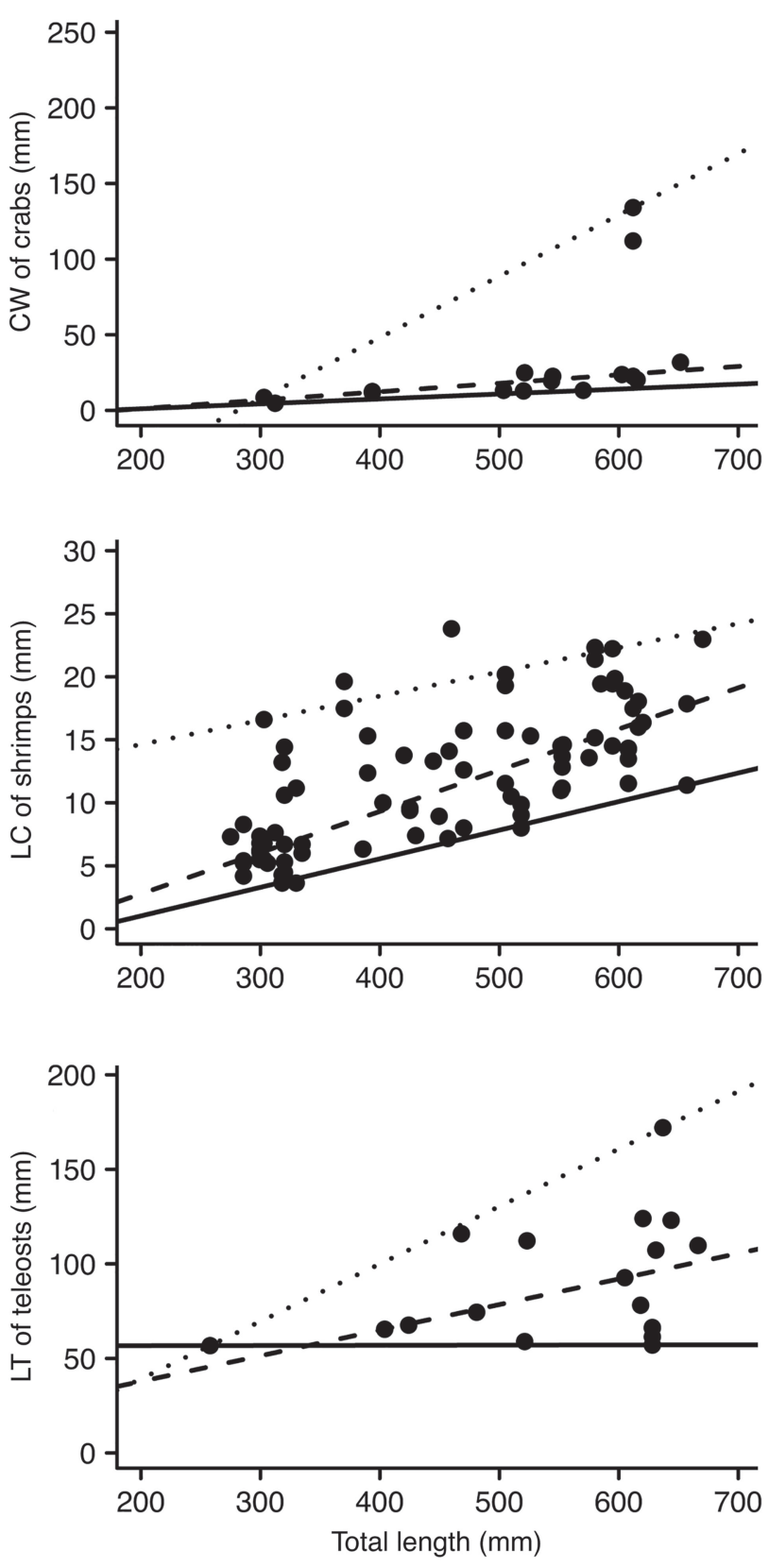

Fig. 5. Quantile regressions of carapace width $(\mathrm{CW})$ of crabs, cephalothorax length (CL) of shrimps and total length (TL) of teleosts and total length of Atlantoraja cyclophora. The solid, dashed and dotted lines are 5\%,50\% and 95\% quantile regressions, respectively.

\section{Discussion}

The diet of Atlantoraja cyclophora consists mainly of decapod crustaceans (shrimps and crabs), benthic teleosts (such as Dules auriga, Porichthys porosissimus and Raneya brasiliensis) and other benthic invertebrates, which implies that this species has demersal-benthic feeding habits. Further, the diet of A. cyplophora changes with ontogeny, season and region, and with size of both predator and prey.
In general, the diet composition of $A$. cyclophora off Uruguay and northern Argentina is consistent with the results obtained in Brazil (Ubatuba Bay, Soares et al., 1992; southern coast of Rio de Janeiro, Viana \& Vianna, 2014), where decapods and teleosts are the most consumed prey. This pattern indicates that $A$. cyclophora maintains its feeding habits along its distribution range in the Southwest Atlantic, using similar food resources and likely having the same trophic role.

Ontogenetic variations in the diet composition of elasmobranchs may be attributed to a combination of different processes: different foraging ability between small and larger individuals, morphological constraints such as gape limitation, and an increase in the metabolic requirements with mature individuals (Wetherbee \& Cortés, 2004). As with another skate species, A. cycplophora showed ontogenetic shifts in the diet composition: small individuals consumed largely shrimps, but large individuals preyed mainly on crabs and teleosts. In southeastern Brazil, the diet of immature and mature individuals was similar, but shrimps were more common in immature individuals and teleosts and crabs were more consumed by mature individuals (Viana \& Vianna, 2014). In general terms, the ontogenetic pattern of A. cyclophora is consistent between regions, which would reflect an identical use of trophic resources throughout its distribution range.

In benthic and demersal coastal communities, species composition is variable, because environmental conditions change seasonally (Jaureguizar et al., 2006). Thus, seasonal changes in the diet are often related with differences in prey abundance between seasons (Muto et al., 2001). In the study area, shrimps are more abundant in the warm season than in the cold season (Iorio et al., 1996; Scelzo et al., 2002), indicating that $A$. cyclophora may be adapting its feeding habits to seasonal changes in prey abundance. In southeastern Brazil, diet composition of A. cyclophora is also related to seasonal prey abundance, but the most important prey consumed in summer were crabs (Viana \& Vianna, 2014). Also, seasonal changes in predation risk may be affecting the feeding habits of $A$. cyclophora, as it is preyed upon by large sharks during the warm season (Lucifora et al., 2009).

An important and consistent pattern found off Uruguayan and northern Argentinean coastal waters is the difference in the diet composition of skates between regions. In several species of skate, the consumption of teleosts fishes is more important in the south region than in the north and the consumption of crustaceans is high in the north region (Rioraja agassizii in Barbini \& Lucifora, 2011; Atlantoraja castelanui in Barbini \& Lucifora, 2012; Sympterygia acuta in Barbini \& Lucifora, 2016). This pattern is identical to the one in A. cyclophora. These spatial dietary changes could be attributed to differences in the structure and abundance of the benthic community between north and south region, caused by 
distinct environmental conditions: in the north area, the Río de la Plata estuary, bottom type, salinity and the presence of a turbidity front structures the benthic communities (Giberto et al., 2004); in the south area, vertical homogeneity due to tidal forcing and a salinity coastal front are the main environment factors (Acha et al., 2004).

Our results show that as $A$. cyclophora increases its body size, the size of shrimps, crabs and teleosts consumed increases too, but larger individuals do not abandon the consumption of small crabs and teleosts. The same pattern is present in other skates that co-occur in time and space, such as Rioraja agassizii (Barbini \& Lucifora, 2011). For both species, we hypothesized that this pattern could be a result of differences in prey availability. Elasmobranchs may be more selective predators in environments with a greater choice of prey (Lucifora et al., 2006). Shrimps (i.e. Artemesia longinaris and Pleoticus muelleri) are abundant species in this region, therefore large individuals of $A$. cyclophora and $R$. agassizii could be more selective, consuming mainly large shrimps. On the other hand, the lower availability of crabs and teleosts may explain the inclusion in the diet of small individuals of these prey by large skates. The predator-prey size pattern found in $A$. cyclophora and $R$. agassizii (i.e. consuming both small and large prey) is the most common among elasmobranchs, specially in piscivorous predators (Scharf et al., 2000; Lucifora et al., 2006).

In conclusion, the ontogenetic diet shifts observed in $A$. cyclophora could be due to a combination of different processes, as improved ability of larger skates, morphological constraints of smaller skates and energy requirements. Seasonal and regional diet shifts could be associated to changes in the prey abundance between seasons and to differences in the environmental conditions between regions, respectively. Differences in availability among prey may explain the pattern that large skates do not abandon the consumption of small individuals of crabs and teleosts. These results bring information on the ecology of an important predator in an ecosystem highly impacted by fishing. Despite this, the life history of A. cyclophora is little known, therefore studies on reproductive aspects and estimates of age and growth parameters are very relevant for the suitable conservation of a vulnerable species that is commercially fished.

\section{Acknowledgements}

The authors would like to thank to the Instituto Nacional de Investigación y Desarrollo Pesquero (INIDEP) for specimens collected. S. A. Barbini was supported by a scholarship from the Comisión de Investigaciones Científicas de la Provincia de Buenos Aires (Argentina).

\section{References}

Acha, E. M., H. W. Mianzan, R. A. Guerrero, M. Favero \& J. Bava. 2004. Marine fronts at the continental shelves of austral South America. Physical and ecological processes. Journal of Marine Systems, 44: 83-105.

Anderson, D. R., K. P. Burnham \& W. L. Thompson. 2000. Null hypothesis testing: problems, prevalence, and an alternative. Journal of Wildlife Management, 64: 912-923.

Barbini, S. A. \& L. O. Lucifora. 2011. Feeding habits of the Rio Skate, Rioraja agassizi (Chondrichthyes, Rajidae), from off Uruguay and north Argentina. Journal of the Marine Biological Association of the United Kingdom, 91: 11751184.

Barbini, S. A. \& L. O. Lucifora. 2012. Feeding habits of a large endangered skate from the Southwest Atlantic: the spotback skate Atlantoraja castelnaui. Marine and Freshwater Research, 63: 180-188.

Barbini, S. A. \& L. O. Lucifora. 2016. Big fish (and a smallish skate) eat small fish: diet variation and trophic level of Sympterygia acuta, a medium-sized skate high in the food web. Marine Ecology, 37: 283-293.

Bornatowski, H., A. F. Navia, R. R. Braga, V. Abilhoa \& M. F. M. Corrêa. 2014. Ecological importance of sharks and rays in a structural foodweb analysis in southern Brazil. ICES Journal of Marine Science, 71: 1586-1592.

Bovcon, N. D., P. D. Cochia, M. E. Góngora \& A. E. Gosztonyi. 2011. New records of warm-temperate water fishes in central Patagonian coastal waters (Southwestern South Atlantic Ocean). Journal of Applied Ichthyology, 27: 832-839.

Colonello, J. H., H. E. Christiansen \& G. J. Macchi. 2011. Escala de madurez sexual para peces cartilaginosos de la Plataforma Continental Argentina. Pp. 115-127. In: Wöhler, O. C., P. Cedrola \& M. B. Cousseau (Eds). Contribuciones sobre biología, pesca y comercialización de tiburones en la Argentina. Aportes para la elaboración del Plan de Acción Nacional. Buenos Aires, Consejo Federal Pesquero.

Cortés, E. 1997. A critical review of methods of studying fish feeding based on analysis of stomach contents: application to elasmobranch fishes. Canadian Journal of Fisheries and Aquatic Science, 54: 726-738.

Cousseau, M. B., D. E. Figueroa, J. M. Díaz de Astarloa, E. Mabragaña \& L. O. Lucifora. 2007. Rayas, chuchos y otros batoideos del Atlántico Sudoccidental ( $\left.34^{\circ} \mathrm{S}-55^{\circ} \mathrm{S}\right)$. Mar del Plata, Instituto Nacional de Investigación y Desarrollo Pesquero, 102p.

Di Giácomo, E. E. \& M. R. Perier. 1996. Feeding habits of cockfish, Callorhinchus callorhynchus (Holocephali: Callorhynchidae), in Patagonian Waters (Argentina). Marine and Freshwater Research, 47: 801-808.

Ebert, D. A. \& J. J. Bizzarro. 2007. Standardized diet compositions and trophic levels of skates (Chondrichthyes, Rajiformes, Rajoidei). Environmental Biology of Fishes, 80: 221-237. 
Franklin, A. B., T. M. Shenk, D. R. Anderson \& K. P. Burnham. 2001. Statistical model selection: an alternative to null hypothesis testing. Pp. 75-90. In: Shenk T. M. \& A. B. Franklin (Eds). Modeling in natural resources management: development, interpretation, and application. Washington, Island Press.

Giberto, D. A., C. S. Bremec, E. M. Acha \& H. Mianzan. 2004. Large-scale spatial patterns of benthic assemblages in the SW Atlantic: the Río de la Plata estuary and adjacent shelf waters. Estuarine Coastal and Shelf Science, 61: 1-13.

Guerrero, R. A. \& A. R. Piola. 1997. Masas de agua de la plataforma continental. Pp. 107-118. In: Boschi, E. E. (Ed). Antecedentes históricos de las exploraciones en el mar y las características ambientales. Mar del Plata, Instituto Nacional de Investigación y Desarrollo Pesquero. (El Mar Argentino y sus Recursos Pesqueros,v. 1).

Heithaus, M. R., A. Frid, A. J. Wirsing \& B. Worm. 2008. Predicting ecological consequences of marine top predator declines. Trends in Ecology and Evolution, 23: 202-210.

Hozbor, N. M. \& A. M. Massa. 2012. Explotación del conjunto de especies de la Familia Rajidae por parte de la flota argentina. Periodo 1992-2011. Mar del Plata, Informe de Investigación No. 55, Instituto Nacional de Investigación y Desarrollo Pesquero $16 \mathrm{p}$.

Iorio, M. I., G. Macchi, C. E. Fischbach \& H. E. Christiansen. 1996. Estudios sobre la dinamica reproductiva del langostino (Pleoticus muelleri) en el área de Bahía Blanca (Provincia de Buenos Aires, República Argentina). Frente Marítimo, 16: 111118.

Jaureguizar, A. J., R. Menni, C. Lasta \& R. Guerrero. 2006. Fish assemblages of the northern Argentine coastal system: spatial patterns and their temporal variations. Fisheries Oceanography, 15: 326-344.

Johnson, J. B. \& K. S. Omland. 2004. Model selection in ecology and evolution. Trends in Ecology and Evolution, 19: 101-08.

Lucas, A. J., R. A. Guerrero, H. W. Mianzán, E. M. Acha \& C. A. Lasta. 2005. Coastal oceanographic regimes of the Northern Argentine Continental Shelf $\left(34^{\circ}-43^{\circ} \mathrm{S}\right)$. Estuarine Coastal and Shelf Science, 65: 405-420.

Lucifora, L. O. 2003. Ecología y conservación de los grandes tiburones costeros de Bahía Anegada, Provincia de Buenos Aires, Argentina. Unpublished Ph. D. Thesis, Universidad Nacional de Mar del Plata, Mar del Plata, Argentina, 406p.

Lucifora, L. O., V. B. García \& A. H. Escalante. 2009. How can the feeding habits of the sand tiger shark influence the success of conservation programs? Animal Conservation, 12: 291-301.

Lucifora, L. O., V. B. García, R. C. Menni \& A. H. Escalante. 2006. Food habits, selectivity, and foraging modes of the school shark Galeorhinus galeus. Marine Ecology Progress Series, 315: 259-270.

Magurran, A. E. 2004. Measuring Biological Diversity. Malden, Blackwell Publishing, 256p.

Massa, A., N. Hozbor \& C. M. Vooren. 2006. Atlantoraja cyclophora. The IUCN Red List of Threatened Species. Available from: www.iucnredlist.org/details/61398/0/ (19 October 2015).
Menni, R. C. \& M. F. W. Stehmann. 2000. Distribution, environment and biology of batoid fishes off Argentina, Uruguay and Brazil. A rewiev. Revista del Museo Argentino de Ciencias Naturales, 2: 69-109.

Muto, E. Y., L. S. H. Soares \& R. Goitein. 2001. Food resource utilization of the skates Rioraja agassizi (Müller \& Henle, 1841) and Psammobatis extenta (Garman, 1913) on the continental shelf off Ubatuba, south-eastern Brasil. Revista Brasileira de Biologia, 61: 217-238.

Navia, A. F., V. H. Cruz-Escalona, A. Giraldo \& A. Barausse. 2016. The structure of a marine tropical food web, and its implications for ecosystem-based fisheries management. Ecological Modelling, 328: 23-33.

Oddone, M. C. \& C. M. Vooren. 2005. Reproductive biology of Atlantoraja cyclophora (Regan, 1908) (Elasmobranchii: Rajidae) off southern Brazil. ICES Journal of Marine Science, 62: 1095-1103.

Oddone, M. C., W. Norbis, P. L. Mancini \& A. F. Amorim. 2008. Sexual development and reproductive cycle of the eyespot skate Atlantoraja cyclophora (Regan, 1903 (Chondrichthyes: Rajidae: Arhynchobatinae), in southeastern Brazil. Acta Adriatica, 49:73-87.

Pinkas, L., M. S. Oliphant \& I. L. K. Iverson. 1971. Food habits of albacore, bluefin tuna and bonito in Californian waters. Fish Bulletin, 152: 1-105.

R Development Core Team. 2012. R: A language and environment for statistical computing. R Foundation for Statistical Computing, Vienna, Austria. Available from http://www.R-project.org/.

Scelzo, M. A., J. M. Arca \& N. M. Lucero. 2002. Diversidad, densidad y biomasa de la macrofauna componente de los fondos de pesca "camarón-langostino", frente a Mar del Plata, Argentina (1998-1999). Revista de Investigación y Desarrollo Pesquero, 15: 43-65.

Scharf, F. S., F. Juanes \& M. Sutherland. 1998. Inferring ecological relationships from the edges of scatter diagrams: comparison of regression techniques. Ecology, 79: 448-460.

Scharf, F. S., F. Juanes \& R. A. Rountree. 2000. Predator size - prey size relationships of marine fish predators: interespecific variation and effects of ontogeny and body size trophic-niche breadth. Marine Ecology Progress Series, 208: 229-248.

Schmitt, J. D., T. Gedamke, W. D. DuPaul \& J. A. Musick. 2015. Ontogenetic and sex-specific shifts in the feeding habits of the barndoor skate. Marine and Coastal Fisheries: Dynamics, Management, and Ecosystems Science, 7: 409418.

Soares, L. S. H., C. L. D. B. Rossi-Wongtschowski, L. M. C. Alvares, E. Y. Muto \& M. A. Gasalla. 1992. Grupos tróficos de peixes demersais da plataforma continental interna de Ubatuba, Brasil. I. Condrichthyes. Boletim do Instituto Oceanográfico, 40: 79-85.

Stevens, J. D., R. Bonfil, N. K. Dulvy \& P. A. Walker. 2000. The effects of fishing on sharks, rays, and chimaeras (chondrichthyans), and the implications for marine ecosystems. ICES Journal of Marine Science, 57: 476-494. 
Symonds, M. R. E. \& A. Moussalli. 2011. A brief guide to model selection, multimodel inference and model averaging in behavioural ecology using Akaike's information criterion. Behavioral Ecology and Sociobiology, 65: 13-21.

Tamini, L. L., G. E. Chiaramonte, J. E. Perez \& H. L. Cappozzo. 2006. Batoids in a coastal fishery of Argentina. Fisheries Research, 77: 326-332.

Venables, W. N. \& D. B. Ripley. 2002. Modern Applied Statistics with S. , 4th ed.. New York, Springer, 498p.

Viana, A. F. \& M. Vianna. 2014. The feeding habits of the eyespot skate Atlantoraja cyclophora (Elasmobranchii: Rajiformes) in southeastern Brazil. Zoologia, 31: 119-125.
Wetherbee, B. M. \& E. Cortés. 2004. Food consumption and feeding habits. Pp 225-246. In: Carrier J. C., J. A. Musick \& M. R. Heithaus (Eds.). Biology of sharks and their relatives. Boca Raton, CRC Press.
Submitted July 08, 2016 Accepted August 04, 2016, by Fernando Gibran 